\title{
Effect of eclampsia on pregnancy outcome at tertiary care center, Gujarat, India
}

\author{
Nidhi Patel ${ }^{1}$, Sumant Shah ${ }^{2 *}$ \\ ${ }^{1}$ Department of Obstetrics and Gynecology, GMERS Medical College, Ahmedabad, Gujarat, India \\ ${ }^{2}$ Department of Obstetrics and Gynecology, BJ Medical College, Ahmedabad, Gujarat
}

Received: 27 January 2019

Accepted: 08 February 2019

\section{*Correspondence:}

Dr. Sumant Shah,

E-mail: drsrshah@gmail.com

Copyright: () the author(s), publisher and licensee Medip Academy. This is an open-access article distributed under the terms of the Creative Commons Attribution Non-Commercial License, which permits unrestricted non-commercial use, distribution, and reproduction in any medium, provided the original work is properly cited.

\begin{abstract}
Background: Eclampsia, a common medical emergency of pregnancy mainly seen in 5\% to $10 \%$ of all pregnancies. The objective of the present study was to study the effect of eclampsia on maternal and perinatal outcome.

Methods: This cross-sectional study was conducted among 50 clinically diagnosed women with eclampsia in their third trimester of pregnancy. Inclusion criteria for the study was; females with singleton pregnancy, all in the third trimester which were diagnosed to have PIH based on the development of hypertension for the first time, proteinuria with or without edema, with no history of previous urinary tract troubles and no evidence of UTI.

Results: Almost $84.0 \%$ participants were belonged to age group of 20 to 30 years age, $54.0 \%$ were belonged to rural area and $92.0 \%$ were belonged to lower socio-economical class, $88.0 \% \%$ participants were registered as emergency case, $34.0 \%$ participants were stayed more than 10 days at hospital and $36.0 \%$ were completed ANC visit. Almost $24.0 \%$ participants were anemic, $6.0 \%$ pre-eclampsic and $4.0 \%$ have tween pregnancy. Severe hypertension at the time of admission were noted in $50.0 \%$ participants followed by absent knee jerk (12.0\%), proteinuria (78.0\%) and edema $(62.0 \%)$ respectively. Maternal mortality and still birth observed in $2.0 \%$ and $18.0 \%$ cases respectively.

Conclusions: Early age, lower socio-economic class, anemia, less ANC clinic visit, higher hospital stay and primigravida observed more among study participants and these factors may play an important role in the pathogenesis of eclampsia.
\end{abstract}

Keywords: Eclampsia, Hypertension, Maternal mortality, Third trimester pregnancy

\section{INTRODUCTION}

The triad of Hypertensive disorders, hemorrhage and infection play a huge role in complicating pregnancy which responsible for a big number of maternal deaths. ${ }^{1,2}$ Eclampsia, a common medical emergency of pregnancy mainly seen in $5 \%$ to $10 \%$ of all pregnancies. ${ }^{3,4}$

It is a pregnancy specific syndrome of reduced organ perfusion secondary to vasospasm and endothelial activation, characterized by hypertension and proteinuira that may lead to multisystem involvement including renal, hematological, hepatic and cerebral impairment.,
Eclampsia become a common cause of maternal mortality nowadays and it is defined as generalized tonic clonic seizures and/or coma in a pregnancy complicated with hypertension. ${ }^{6,7}$ It is mostly observed more among nulliparous women.

Exact etiology does not revealed till date but obesity, diabetes, magnesium deficiency, older maternal age and job stress play crucial role in the pathogenesis of eclampsia. $^{2,8-10}$ Haemodilution, renal clearance, consumption of minerals by the growing fetus is concerned with the hypomagnesaemia in pregnant women. There is decrease in ionized and total magnesium 
levels with increasing gestational age during normal pregnancy, as well as evidence of magnesium disturbance in women who later developed Eclampsia. Magnesium levels may have significant effects on cardiac excitability and on vascular tone, contractility and reactivity. Magnesium causes vascular muscle relaxation. ${ }^{11-13}$. So this study was conducted with the objective to study the effect of eclampsia on maternal and perinatal outcome.

\section{METHODS}

This is a cross-sectional study included 50 pregnant women between 20-35 years of age, attending Gynaecology OPD/admitted in Gynaecology wards in tertiary care hospital, Ahmedabad, Gujarat.

Study was conducted among 50 clinically diagnosed women with eclampsia in their third trimester of pregnancy represented as study group during April 2011 to March 2013 after permission of Institutional Ethical Committee (IEC). Inclusion criteria for the study was; All were in the same previously mentioned criteria but didn't develop hypertension.

\section{Inclusion criteria}

- Females with singleton pregnancy.

- All in the third trimester which were diagnosed to have PIH based on the development of hypertension for the first time.

- Proteinuria with or without edema, with no history of previous urinary tract troubles and no evidence of UTI.

\section{Exclusion criteria}

- Pregnant ladies with medical complications such as renal disease, trophoblastic disease, heart disease, chronic hypertension and on magnesium sulphate drugs.

Thorough clinical examination was carried out before recruiting the participants for the study by a competent gynecologist.

Personal and clinical information regarding age, gestational age, socioeconomic status, education, dietary habit, clinical and biochemical parameters were recorded with the help of a questionnaire, with prior consent of the participant.

All the statistical tests were performed in Epi Info 3.5.1 software by CDC, USA.

\section{RESULTS}

Table 1 shows that $84.0 \%$ participants were belonged to age group of 20 to 30 years age group followed by $8.0 \%$ in age group of $<20$ years and $>30$ years respectively. Almost $70.0 \%$ participants were housewife and $30.0 \%$ were labourer. Around $54.0 \%$ were belonged to rural area and $92.0 \%$ were belonged to lower socio-economical class. Almost $88.0 \% \%$ participants were registered as emergency case. Almost $34.0 \%$ participants were stayed more than 10 days at hospital.

Table 1: Clinico-social factors of study participants ( $\mathrm{N}=\mathbf{5 0})$.

\begin{tabular}{|c|c|}
\hline Variables & Number $(\%)$ \\
\hline \multicolumn{2}{|l|}{ Age (in year) } \\
\hline$<20$ & $4(8)$ \\
\hline $20-30$ & $42(84)$ \\
\hline$>30$ & $4(8)$ \\
\hline Mean age \pm SD & $24.3 \pm 5.1$ \\
\hline \multicolumn{2}{|l|}{ Occupation } \\
\hline Housewife & $35(70)$ \\
\hline Labourer & $15(30)$ \\
\hline \multicolumn{2}{|l|}{ Residence } \\
\hline Rural & $27(54)$ \\
\hline Urban & $23(46)$ \\
\hline \multicolumn{2}{|c|}{ Socio-economic class } \\
\hline Lower & $46(92)$ \\
\hline Middle & $3(6)$ \\
\hline Upper & $1(2)$ \\
\hline \multicolumn{2}{|l|}{ Type of case } \\
\hline Booked & $6(12)$ \\
\hline Emergency & $44(88)$ \\
\hline \multicolumn{2}{|c|}{ Total hospital stay } \\
\hline$<5$ & $1(2)$ \\
\hline $5-10$ & $32(64)$ \\
\hline$>10$ & $17(34)$ \\
\hline \multicolumn{2}{|c|}{ Amenorrhea (in month) } \\
\hline $5-7$ & $9(18)$ \\
\hline 8 & $15(30)$ \\
\hline 9 & $26(52)$ \\
\hline \multicolumn{2}{|l|}{ Ante-natal visit } \\
\hline Yes & $18(36)$ \\
\hline No & $32(64)$ \\
\hline \multicolumn{2}{|l|}{ Parity } \\
\hline Primi & $35(70)$ \\
\hline Multi & $15(30)$ \\
\hline \multicolumn{2}{|l|}{ Risk factor } \\
\hline Anemia & $12(24)$ \\
\hline Pre-eclampsia & $3(6)$ \\
\hline Twins & $2(4)$ \\
\hline Heart Disease & $1(2)$ \\
\hline Malaria & $1(2)$ \\
\hline
\end{tabular}

Only $36.0 \%$ were completed ANC visit, 52.0\% participants have 9 months of amenorrhea and $15.0 \%$ were multi-gravida patients. Almost $24.0 \%$ participants were anemic, $6.0 \%$ pre-eclampsic and $4.0 \%$ have tween pregnancy. Table 2 shows that $24.0 \%$ participants have history of $>3$ convulsion episode and same were came directly from home. Severe hypertension at the time of admission were noted in $50.0 \%$ participants followed by absent knee jerk (12.0\%), proteinuria (78.0\%) and edema 
(62.0\%) respectively. Altered respiratory, CNS system were noted in $24.0 \%$ and $36.0 \%$ cases respectively. Almost all the cases have history of first time of convulsion episode. Maternal mortality and still birth observed in $2.0 \%$ and $18.0 \%$ cases respectively. I

Table 2: Eclampsia related variables observed among study participants $(\mathrm{N}=\mathbf{5 0})$.

\begin{tabular}{|l|l|}
\hline Variable & Number $(\%)$ \\
\hline No. of convulsion & $38(76)$ \\
\hline$\leq 3$ & $12(24)$ \\
\hline$>3$ & $12(24)$ \\
\hline Referred & $38(76)$ \\
\hline Directly home & \\
\hline Hospital & $25(50)$ \\
\hline BP at the time of admission & $19(38)$ \\
\hline Severe & $6(12)$ \\
\hline Mild & \\
\hline Normal & $6(12)$ \\
\hline Knee jerk & $31(62)$ \\
\hline Absent & $13(26)$ \\
\hline Brisk & \\
\hline Normal & $39(78)$ \\
\hline Proteinuria $(\mathbf{n}=\mathbf{4 8})$ & $6(12)$ \\
\hline+1 to +4 & $2(4)$ \\
\hline Trace & $31(62)$ \\
\hline NIL & \\
\hline Edema & $12(24)$ \\
\hline Present & $18(36)$ \\
\hline Respiratory system & $13(26)$ \\
\hline Altered & $0(0.0)$ \\
\hline CNS & $1(2)$ \\
\hline Altered & \\
\hline Platelet count & \\
\hline Low & \\
\hline Reoccurrence & \\
\hline Yes & \\
\hline Maternal mortality & \\
\hline Yes & \\
\hline Perinatal outcome & \\
\hline Live birth & \\
\hline Still birth & \\
\hline
\end{tabular}

\section{DISCUSSION}

During pregnancy, urinary excretion of magnesium also increased due to hemodilution effect of oestrogen and increased demand of fetus decrease the serum magnesium level. ${ }^{2,14}$ Present study observed that more than $4 / 5^{\text {th }}$ participants were belonged to age group 20 to 30 years and mean age was 24.1 year. This finding is nor correlate with the study done by Tavana $\mathrm{Z}$ et al and Darkwa EO et al16 but correlate with the study finding Singh A et al. ${ }^{15,16}$ Although this is a well-established fact that preeclampsia and eclampsia are more prevalent in extremes of age Pregnant women of age less than 20 year were higher risk of developing pre-eclampsia compared to age of more than 20 year. ${ }^{17,18}$ More than
$2 / 5^{\text {th }}$ participants were housewife and more than half participants were resided in rural area and almost more than $90 \%$ were came from lower socio-economical class. One of the strong risk factors for preeclampsia is Low maternal socioeconomic status. ${ }^{19}$ Average duration of most of participants were stayed at hospital for more than 5 days and out of that, almost $90.0 \%$ cases were admitted as emergency case and this finding is correlate with the study done by Sandhu et al and Gaddi $\mathrm{S}$ et al. ${ }^{20,21}$ Diastolic blood pressure, the interval between onset of eclampsia and delivery, mode of delivery, and duration of magnesium therapy play an important role in length of hospital stay of eclamptic patients. ${ }^{22}$

Only $1 / 3^{\text {rd }}$ cases were attended ANC clinic during their pregnancy period, and more than $2 / 3$ rd cases were primigravida. Eclampsia is more common in primigravida women and the risk of preeclampsia increases the greater the interval between pregnancies. Present study observed anemia as common risk factors among study participants. women with severe anaemia had a very much greater risk of eclampsia than women with no anaemia. ${ }^{23,24}$

More than $1 / 4^{\text {th }}$ participants have history of $>3$ convulsion and more than $50.0 \%$ cases have higher blood pressure. Abnormal knee jerk was observed in 3/4th participants, proteinuria presents in more than $90.0 \%$ cases, edema present in $3 / 5^{\text {th }}$ cases. Present study noted maternal mortality in one case and still birth in $18.0 \%$ cases. Elevated systolic blood pressure and raised aspartate aminotransferase levels observed in primigravida indicate a more severe form of Eclampsia. ${ }^{25}$

\section{CONCLUSION}

Present study results revealed that early age, lower socioeconomic class, anemia, less ANC clinic visit, higher hospital stay and primigravida observed more among study participants and these factors may play an important role in the pathogenesis of eclampsia. Screening of this factors and correction of the same in pregnancy may prevent the risk of developing eclampsia.

Funding: No funding sources

Conflict of interest: None declared

Ethical approval: The study was approved by the Institutional Ethics Committee

\section{REFERENCES}

1. Malas NO, Shurideh ZM. Does serum calcium in pre-eclampsia and normal pregnancy differ? Saudi Med J. 2001;22(10):868-71.

2. Purohit A, Vyas RK, Sharma ML, Soni Y, Verma A. Serum magnesium status in preeclampsia. Int $\mathrm{J}$ Med Sci Education. 2016;3(1):1-8.

3. Omu AE, Al-Harmi J, Vedi HL, Mlechkova L, Sayed AF, Al-Ragum NS. Magnesium Sulphate Therapy in Women with Pre-Eclampsia and Eclampsia in Kuwait. Med Princ Pract. 2008;17(3):227-32. 
4. Singh A, Verma AK, Hassan G, Prakash V, Sharma P. Serum magnesium levels in patients with preeclampsia and eclampsia with different regimens of magnesium sulphate. GJMEDPH 2013;2(1):1-9.

5. Cunningham FG, Pritchard JA. How should hypertension during pregnancy be managed? Experience at Parkland Memorial Hospital. Medic Clinics North Am. 1984;68(2):505-26.

6. Tomlinson TM, Sadovsky Y. Pregnancy: preeclampsia and eclampsia. In: Kollef MH,Bedient TJ, Isakow W, Witt CA. The Washington Manual of Critical Care, 8thed.NewYork : Wolters-Lippincott Williams and Wilkins 2010.439-445.

7. Duley L: Maternal mortality associated with hypertensive disorders of pregnancy in Africa, Asia, Latin America, Caribbean. $\mathrm{Br}$ J Obtet Gynaecol,1992;99(7):547-53.

8. Siabai B. Prevention of preeclampsia: a big disappointment. Am J Obstet Gynaecol. 1998;179(5):1275-8.

9. Hojo M, August P. Magnesium metabolism in preeclampsia: supplementation may help. Medscape Women Health. 1997;2(1):5.

10. Marcoux S, Berube S, Brisson C, Mondor M. Job Strain and pregnancy induced hypertension. Epidemiol. 1999;10:376-82.

11. Pairu J, Triveni GS, Manohar A. The study of serum calcium and serum magnesium in pregnancy induced hypertension and normal pregnancy. Int $\mathbf{J}$ Reprod Contracep Obstet Gynecol. 2015;4(1):30-4.

12. Tong GM, Rude RK. Magnesium deficiency in critical illness. J Intensive Care Med. 2005;20(1):317.

13. Touy ZRM. Role of magnesium deficiency in pathogenesis of hypertension. Mol Aspects Med. 2003;24(10):107-36.

14. Kisters K, Barenbroka M, Louwenb F, Hausberga M, Rahna KH, Koscha M. Membrane, intracellular and plasma magnesium, and calcium concentrations in preeclampsia. Am J Hypertens. 2000;13(7):765-9.

15. Tavana Z, Hosseinmirzaei S. Comparison of Maternal Serum Magnesium Level in Pre-eclampsia and Normal Pregnant Women. Iran Red Cres Med J. 2013;15(12):e10394.
16. Darkwa EO, Charles AB, Robert D, Owooo C. Serum magnesium and calcium in preeclampsia: a comparative study at the Korle-Bu Teaching Hospital, Ghana. Integ Blood Press Cont 2017;10:915.

17. Kumar R, Gandhi S, Rao V. Socio-Demographic and Other Risk Factors of Pre-Eclampsia at a Tertiary Care Hospital, Karnataka: Case Control Study. J Clinic Diagnos Research.2014;8(9):1-4.

18. Duckitt K, Harrington D. Risk factors for preeclampsia at antenatal booking: systematic review of controlled studies. BMJ.2005;330(7491):565-77.

19. Silva LM, Coolman M, Steegers EA, Jaddoe VW, Moll HA, Hofman A. Low socioeconomic status is a risk factor for preeclampsia: The Generation $\mathrm{R}$ Study. J Hypertens. 2008;26(6):1200-8.

20. Sandhu G, Ramaiyah S, Chan G, Meisels I. Pathophysiology and Management of PreeclampsiaAssociated Severe Hyponatremia. AJKD 2010;55(3):599-603.

21. Gaddi suman,Somegowdel : maternal and perinatal outcome in Eclampsia in district hospital; VIMS, Bellary. J Obstet Gynecol India 2007/57(4):324-6.

22. Maray P, Emin U, Omer LT, Tuncay G. Factors influencing the postpartum length of hospital stay in eclamptic women. Taiwan J Obstet Gynecol. 2007;46(4):410-3.

23. English FA, Kenny LC, Mccarthy FP. Risk factors and effective management of preeclampsia. Integ Blood Pressure Cont 2015;8:7-12.

24. Ali et al:: Severe anaemia is associated with a higher risk for preeclampsia and poor perinatal outcomes in Kassala hospital, eastern Sudan. BMC Res Notes. 2011;4(1):311.

25. Barden AE, Beilin LJ, Ritchie J, Barry NW. Is proteinuric pre-eclampsia a different disease in primigravida and multigravida? Clinical Sci 1999;97(4):475-483.

Cite this article as: Patel N, Shah S. Effect of eclampsia on pregnancy outcome at tertiary care center, Gujarat, India. Int J Reprod Contracept Obstet Gynecol 2019;8:858-61. 